\title{
Correction to: A robust strategy for proteomic identification of biomarkers of invasive phenotype complexed with extracellular heat shock proteins
}

\author{
Steven G. Griffiths ${ }^{1} \cdot$ Alan Ezrin $^{2} \cdot$ Emily Jackson $^{3} \cdot$ Lisa Dewey $^{3} \cdot$ Alan A. Doucette $^{4}$
}

Accepted: 10 December 2020 / Published online: 23 December 2020

(C) Cell Stress Society International 2020

\section{Correction to: Cell Stress Chaperones (2019) 24: 1197-1209} https://doi.org/10.1007/s12192-019-01041-8

In the original version of this article the following note was missing: The Vn96 peptide (US Patent \# 8,956,878) that was central to this study was purchased as part of the $\mathrm{ME}^{\mathrm{TM}} \mathrm{Kit}$ for exosome isolation from New England Peptide (Gardner, MA, USA).

Publisher's note Springer Nature remains neutral with regard to jurisdictional claims in published maps and institutional affiliations.

The online version of the original article can be found at https://doi.org/ 10.1007/s12192-019-01041-8

\footnotetext{
Alan A. Doucette

alan.doucette@dal.ca

1 X0S0ME, Moncton, New Brunswick, Canada

2 NX Development Corporation, Louisville, KY, USA

3 David H. Murdock Research Institute, Kannapolis, NC, USA

4 Dalhousie University, Halifax, Nova Scotia, Canada
} 